\title{
Parental Support for Speech Delay in Early Childhood in Kalisari Village, Natar District, South Lampung Regency
}

\section{Hetty Anggraini, Nurul Ramadhani}

\author{
STKIP AL-Islam Tunas Bangsa \\ hettyanggraini@stkipalitb.ac.id
}

Submitted : 2021-11-18, Revised : 2021-11-25, Accepted : 2021-11-30

\begin{abstract}
This study was aims to explore, describe, and analyze parent support for the speech delay early childhood. This study used to the qualitative method of the research subject is both parents of children who experience speech delay in Kalisari village. This study was used to three methods of data collection, namely observation, interviews, and documentation. The data analyze used to descriptive qualitative. Based on the results of the discussion that has been described it can be concluded that parent support that has been given to children who experience speech delay is informational support, assessment support, instrumental support, emotional social support, and real support. Of the five supports, the researchers concluded that the support often used by subjects was informational support, namely parents provided support through the provision of good advice and advice, giving instructions by installing pictures in the refrigerator so that the twins could understand the food taken and want to say food they took, and provided information by taking the twins for a walk to get a new vocabulary.
\end{abstract}

Keywords: Early Childhood; Parent support; Speech Delay

\section{Introduction}

Language is a form of rule or symbol system that children use in communicating and adapting to their environment to exchange ideas, thoughts, and emotions (Nugraha, 2018). Language can be expressed through speech referring to verbal symbols, in addition to using verbal symbols, language can also be expressed through writing, gestural signs, and music (Kurniati, 2017). Language can also include aspects of nonverbal communication such as gestures, gestures or pantomimes. The ability to speak and language involves the development of cognitive, sensory motor, psychological, emotional, and the environment around children (including parents). Language skills in general can be distinguished into receptive (hearing and understanding) and expressive (speaking) abilities (Fitriani et al., 2019). Speaking ability can be assessed more than other abilities so that discussions about language skills are more often associated with speaking skills, language skills and speaking are influenced by intrinsic factors (children) and extrinsic factors (environment) (Hartanto et al., 2016). Intrinsic factor is where the innate condition of the child from birth includes the physiology of the organs involved in the ability to speak, while the extrinsic factor is in the form of a stimulus that is around the child, especially the words that are heard or addressed to the child.

Some data show that the incidence of children experiencing speech delay is quite high. Research in New Zealand found that $8.4 \%$ of children aged 5 years experienced speech delays, while in Canada it was 3\% to $10 \%$. As is known delay in speech refers to the barriers and development of children. Speech disorder in children is the ability to speak that is not appropriate when compared to children of the same age (Widyawaty, 2021).

According to Hurlock (2009), the definition of speech delay in children is if the level of speech development is below the level of quality of speech development of children in general the same can be seen from the accuracy of the use of words. As stated by Campbell, who tried to reveal the risk factors for speech delay in children of unknown or mixed race at the age of 3 years, the results of his research revealed that the male sex had a large ratio in influencing speech delay. The ability to speak in children starts from the family, school, community environment. The family is the "madrasatul ulla" or the first school for children before they are in school education level because the family is the main determining factor in various aspects of development, if the family, especially parents, is late in stimulating children's 
language skills, their speech development will be hampered in the future. According to the statement (Santrock et al., 2008) language progress that occurs in early childhood provides the foundation for further child development at elementary school age.

Children who are late in speaking are children who have a tendency to say the wrong words, then have a poor vocabulary at the age of 3 years, or also have difficulty naming objects at the age of 5 years (Papalia, 2015). And children like that, later have a tendency to be unable to read. "children who show an unusual tendency to mispronounce words at age 2, who have poor vocabulary at age 3 , or who have trouble naming objects at 5 are apt to have reading disabilities later on. misinterpreting words at age 2 , who have poor vocabulary at age 3 , or who have problems with object planting at age 5 tend to have reading disabilities later in life. Based on the opinion which has been described above, it can be concluded that the definition of a child who has a speech delay is a child whose level of quality of speech development is below that of a child of his age.

Language development in children cannot be separated from the role of the child's parents. Children first learn everything in the family environment and parents are the first teachers for children. This makes parents have a big role in the education of their children, both in terms of time, material and energy. Based on observations in PAUD, there are still children who experience delays in speaking. This happened to the Dahlia PAUD institution which had the address at Jalan Sitara, Kalisari Village, Natar Subdistrict, South Lampung, which should have been aged 4-6 years, children could speak (language) well and clearly, but in this PAUD institution there were still children who were not clear in speaking and inaccuracies. spoken word.

There are many causes of speech delays, the most common of which is a low level of intelligence that makes it impossible for children to learn to speak as well as their normal or high intelligence peers; lack of motivation because children know they can communicate adequately with pre-speech forms parents encourage to continue using "baby talk" because they think it is "sweet"; limited opportunities to practice speaking due to strict limits on how much they are allowed to talk at home; constantly hanging out with twins who can understand their special speech and bilingual use at home which slows down the learning of their mother tongue. Speech delays can be seen from the fact that if parents not only talk to their children but also use a wide variety of words, the child's speech ability will develop rapidly (Muslimat et al., 2020). According to Hurlock, the factors that influence the number of children talking are as follows: the factors that affect the number of children speak as follows: intelligence, type of discipline, position of order, family size, socioeconomic status, racial status, bilingualism, sex role classification (Rahman, 2009).

\section{Methods}

This study uses a qualitative method. The subjects in this study were parents of two children who had speech delays. Determination of the subject is done by purposive sampling technique with consideration is parents by using social mapping. The data collection technique used in this study is the method of participant observation, structured interviews, and documentation.

\section{Results and Discussion}

Parents function as a collector (collector) and disseminator (spreader) of information about various things (Tanjung \& Satyawan, 2021). Explains about giving advice, suggestions, information that can be used to reveal and solve a problem. The benefit of informational support is that it can suppress the emergence of an understanding because of the information provided and can contribute suggestions and actions to individuals (Cahyadi, 2012). Aspects in this support are advice, suggestions, instructions, and information provision. With regard to 
informational support, the researcher found in subject A the support that had been given in the form of advice to the twins. The same thing was conveyed in an interview with subject B who stated that the support provided was in the form of advice to the twins. In addition to informational support in the form of advice, the subject also provided informational support in the form of suggestions given to the twins. In addition to informational support in the form of advice and suggestions, there is also informational support in the form of providing information. The following is the information that subject A gave to the twins. In accordance with the statement of subject A, the support that has been given to the twins, subject B has also provided informational support in the form of providing information. The last part of the informational support is the informational support part of the instructions, namely the instructions given to the twins, the researcher found that subject A had given instructions to the twins. The same thing was also expressed by subject B, the support given to the twins in the form of instructions. Regarding the statements given by the two subjects, the interview excerpt above was also conveyed and justified by the subject $\mathrm{C}$.

Parents as a safe and peaceful place for rest and recovery and help control emotions (Silfi et al., 2020). Aspects of emotional support include support that is manifested in the form of trust, attention, listening and being listened to (Susanti \& Sulistyarini, 2013). Related to the emotional social support given by parents to children who have speech delays, the researchers found that subject A had provided emotional social support in the form of lack of trust in the twins. The same thing was also expressed by subject B, emotional social support in the form of trust has been given to the twins. From the expression of emotional social support in the form of trust given to the twins, the researchers looked for the truth of this to the subject $\mathrm{C}$.

In addition to emotional social support in the form of trust, there is also emotional social support in the form of listening and being listened to which is given to children who experience speech delays (Ernawati \& Heryani, 2015). The same thing was also expressed by subject B regarding emotional social support in the form of listening and being listened to to the twins. Regarding the expressions of the two subjects above, the researcher also received information from subject $\mathrm{C}$, the support given to the twins by the two subjects above, namely in the form of listening and being listened to.

Parents act as a guide that is feedback, guide and mediate in the problem solving process, as a source and validator of the identity of parent members, which include giving attention and appreciation. Regarding the assessment support given by the parents to the twins, the researcher found that subject A had provided feedback to the twins. The same thing related to the interview excerpt of subject A was also conveyed in the interview, subject B stated that the support provided was in the form of feedback. Regarding the statements from subject $\mathrm{A}$ and subject $\mathrm{B}$, the researcher also got the truth from subject $\mathrm{C}$, assessment support in the form of feedback given to the twins. With the support of the assessment, the researcher also found that subject A had provided support in the form of appreciation for the twins. The same thing was conveyed by subject B related to the interview above, subject B also stated the support given in the form of awards. Related to the statement of the two subjects, the researcher also found the truth revealed by subject A and B, the truth was obtained from subject $\mathrm{C}$.

Parents act as guides, namely feedback, guides and mediators in the problem-solving process, as sources and validators of the identity of parent members, which include giving attention and appreciation (Miarso, n.d.). Regarding the assessment support given by parents to the twins, the researcher found that subject A had provided feedback to the twins. The same thing related to the interview excerpt of subject A was also conveyed in the interview, subject B stated that the support provided was in the form of feedback. Regarding statements from subject $\mathrm{A}$ and subject $\mathrm{B}$, the researcher also got the truth from subject $\mathrm{C}$, assessment support in the form of feedback given to the twins. With the support of this assessment, the researcher also found that subject $\mathrm{A}$ had provided support in the form of appreciation for the twins. The 
same thing was conveyed by subject B related to the interview above, subject B also stated the support given in the form of awards. Regarding the statements of the two subjects, the researcher also found the truth expressed by subjects $\mathrm{A}$ and $\mathrm{B}$, the truth was obtained from subject C.

Assessment support in addition to feedback and awards there is also assessment support in the form of attention, namely the researcher found the assessment support given to the twins in the form of attention. The same thing was also expressed by subject B and confirmed by subject $\mathrm{C}$.

While virtually anyone can provide support in the form of money and attention, tangible support is most effective when it is well appreciated by the recipient. Giving real support that results in feelings of disorganization and unfavorable acceptance will actually add to the individual pressure and stress in the parent's life. Forms of this tangible support, among others, such as attention and material. With regard to real support, the researcher found that subject $\mathrm{A}$ provided tangible support in the form of material to the twins. The same thing was also expressed by subject B regarding the real support in the form of materials that had been given to the twins. The statement given by the two subjects above about real support in the form of material that has been given to the twins, the researcher also got data from subject $\mathrm{C}$ about the truth of the support that has been given to the twins.

Parents are a source of practical and concrete help, which seeks to provide the facilities and equipment needed by each parent member. Regarding instrumental support, the researcher found that subject A had provided instrumental support in the form of providing the facilities needed by the twins. The same thing was also expressed by subject $\mathrm{B}$, the support provided was in the form of providing facilities for the twins.

1. Informational support

Parents function as a collector (collector) and disseminator (spreader) of information about various things. Explains about giving advice, suggestions, information that can be used to reveal and solve a problem. The benefit of this support is that it can suppress the emergence of an understanding because of the information provided and can contribute suggestions and actions to individuals. Aspects in this support are advice, suggestions, instructions, and information provision.

2. Emotional social support

Parents as a safe and peaceful place for rest and recovery and help control emotions. Aspects of emotional support include support that is manifested in the form of trust and listening. Parents have not given full trust to the twins. Then, with special emotional support in the form of listening and being listened to, it is also very important for children who are late to speak because they listen to children who speak even though their vocabulary is not yet clear. Parents listen to the words of the twins, parents also need to be listened to by the twins so far the twins really listen to what their parents say and they always obey their parents because the twins are always given good things before their parents give the rules or prohibitions given to them.

3. Rating support

Parents act as a guide that is feedback, guide and mediate in the problem solving process, as a source and validator of the identity of parent members which include providing support, attention, and appreciation.

4. Real support

While virtually anyone can provide support in the form of money and attention, tangible support is most effective when it is well appreciated by the recipient. Giving real support that results in feelings of disorganization and unfavorable acceptance will actually add to the individual pressure and stress in the parent's life. The forms of this tangible support include attention and material. 


\section{Instrumental support}

Parents are a source of practical and concrete help, which seeks to provide the facilities and equipment needed by each parent member. The facilities provided are in the form of books, picture books, pencils, colored pencils and pictures that can be pasted and educational toys.

\section{Conclusions and Suggestions}

Based on the results of the study, it can be concluded that the parental support that plays a very important role is informational support. Parents must provide good advice and suggestions, provide instructions, and provide information to children who have speech delays so that children's speech development can develop properly. Researchers suggest that parents provide more support in the form of informational support in the form of good advice and suggestions, suggestions, information and instructions for children who experience speech delays. Researchers suggest early childhood education teachers to better understand parental support for speech delay problems, especially informational support. Future researchers are expected to maximize other research approaches. Such as parental support for speech delays can be measured with a more measurable scale so that it is known and explored and other researchers are expected to be able to adjust the mix method (qualitative-quantitative).

\section{References}

Cahyadi, A. (2012). Konflik peran ganda perempuan menikah yang bekerja ditinjau dari dukungan sosial keluarga dan penyesuaian diri. Widya Warta: Jurnal Ilmiah Universitas Katolik Widya Mandala Madiun, 36(02), 254-271.

Ernawati, M., \& Heryani, E. (2015). Hubungan Dukungan Keluarga Dengan Interaksi Sosial Pada Anak Autis di SLB Prof. Dr Sri Soedewi Masjhun Sofwan Sh Jambi Tahun 2015. Jurnal Poltekkes Jambi, 8, 1677-2085.

Fitriani, D., Fajriah, H., \& Rahmita, W. (2019). Media Belajar Big Book dalam Mengembangkan Kemampuan Berbahasa Reseptif Anak Usia Dini. Jurnal Obsesi: Jurnal Pendidikan Anak Usia Dini, 4(1), 237-246.

Hartanto, F., Selina, H., Zuhriah, H., \& Fitra, S. (2016). Pengaruh perkembangan bahasa terhadap perkembangan kognitif anak usia 1-3 tahun. Sari Pediatri, 12(6), 386-390.

Hurlock, E. B. (2009). Psikologi perkembangan: suatu perkembangan sepanjang rentang kehidupan. Jakarta: Erlangga.

Kurniati, E. (2017). Perkembangan Bahasa pada Anak dalam Psikologi Serta Implikasinya dalam Pembelajaran. Jurnal Ilmiah Universitas Batanghari Jambi, 17(3), 47-56.

Miarso, Y. (n.d.). C. Perubahan Paradigma Pembelajaran dengan Kehadiran Teknologi Informasi. Sensi Pengembangan Pembelajaran Berbasis Multimedia, 26.

Muslimat, A. F., Lukman, L., \& Hadrawi, M. (2020). Faktor Dan Dampak Keterlambatan Berbicara (Speech Delay) Terhadap Perilaku Anak Studi Kasus Anak Usia 3-5 Tahun: Kajian Psikolinguistik. Jurnal Al-Qiyam, 1(2), 1-10.

Nugraha, O. A. (2018). Pemerolehan Bahasa Anak Usia 4 Tahun Kajian Semantik Penyimpangan Tuturan Anak. Kajian Linguistik Dan Sastra, 2(2), 104-110.

Papalia, D. E. (2015). Experience human development. 
Rahman, U. (2009). Karakteristik perkembangan anak usia dini. Lentera Pendidikan: Jurnal Ilmu Tarbiyah Dan Keguruan, 12(1), 46-57.

Santrock, J. W., MacKenzie-Rivers, A., Leung, K. H., \& Malcomson, T. (2008). Life Span. Boston: McGraw-Hill.

Silfi, F., Retnowati, L., \& Hidayah, N. (2020). erbedaan Pola Asuh Orang Tua Dengan Penggunaan Gadget Pada Anak di TK Kristen Atambua NTT dan TK An-Nur Mancar Peterongan Jombang. Hospital Majapahit (JURNAL ILMIAH KESEHATAN POLITEKNIK KESEHATAN MAJAPAHIT MOJOKERTO), 12(2), 104-115.

Susanti, M. L., \& Sulistyarini, T. (2013). Dukungan keluarga meningkatkan kepatuhan diet pasien diabetes mellitus di ruang rawat inap RS. Baptis Kediri. Jurnal Stikes, 6(1), 1-10.

Tanjung, N. K., \& Satyawan, L. I. (2021). Hubungan antara Dukungan Sosial Orang Tua dan Grit pada Siswa TNI di Lembaga 'X'Kota Bandung. Humanitas, 5(1).

Widyawaty, E. D. (2021). Faktor-Faktor Yang Mempengaruhi Kejadian Keterlambatan Bicara Di House Of Fatima Child Center Kota Malang. Health Care Media, 5(1), 29-32. 